\title{
TRACKING THE CULTURE OF LEARNING AND READINESS FOR LEARNER AUTONOMY IN A TURKISH CONTEXT
}

\author{
Galip Kartal $^{\mathrm{a}}$, Cem Balçıkanlı ${ }^{\mathrm{b}}$ \\ ( ${ }^{a}$ gkartal@konya.edu.tr) \\ Necmettin Erbakan University \\ Ahmet Keleşoğlu. Faculty of Education, Askan Mahallesi. Meram, Konya, \\ Turkey, 42090 \\ ( ${ }^{b}$ balcikanli@gazi.edu.tr) \\ Gazi University \\ Gazi Faculty of Education, Teknikokullar, Beşevler Ankara, Turkey, 06500
}

\begin{abstract}
This study aims to investigate ELT student teachers' culture of learning and their readiness for becoming autonomous and promoting their students' learner autonomy in a Turkish context. Data were collected through two questionnaires (Culture of Learning Questionnaire and Learner Autonomy Readiness Questionnaires) and semi-structured interviews. The questionnaires were completed by 110 fourth-year student teachers of English who were studying at a Second Language Teacher Education (SLTE) program of a university in Turkey. Interviews were conducted with 23 volunteer participants for deeper understanding of the constructs investigated. Findings indicate that the participants did not come from a learning environment in which autonomy was fostered. However, they indicate their readiness to take some responsibility for their own language learning and implementing more autonomous activities outside the classrooms. In terms of their becoming teachers in the future, they are not fully ready for promoting learner autonomy among their future students, but they consider learner autonomy important and plan to take small steps to create an autonomysupportive environment.
\end{abstract}

Keywords: learner autonomy, student teachers, culture of learning, high school, second language teacher education

DOI: http://dx.doi.org/10.15639/teflinjournal.v30i1/22-46 
Learner autonomy has become an important aspect of language education with the increasing attention given to learner-centred approaches since the use of the term by Holec (1981). Fostering learner autonomy is crucial as "[learner autonomy] is viewed as both a desirable goal of education and a constituent element of good teaching and learning" (Benson \& Huang, 2008, p. 422). Baume (1994) asserts that one of the key goals of higher education should be to foster learner autonomy. In a similar vein, the importance of learner autonomy in language teaching and second language teacher education (SLTE) programs cannot be underestimated. According to Tschirhart and Rigler (2009), fostering learner autonomy should be an integral part of modern language teaching because if students become responsible for their own learning process, language learning will be more efficient (Benson, 2001; Chan, 2016; Dafei, 2007; Illes, 2012; Little, 2008; Myartawan, Latief, \& Suharmanto, 2013; Ribbe \& Benazilla, 2013; Scharle \& Szabo, 2000).

It is necessary to understand learner autonomy so that teachers can promote it (Little, 2007). Learner autonomy is commonly defined as either the ability to take charge of one's own learning (Field, 2007; Holec, 1981) or the capacity to take control over one's own learning (Benson, 2001). As autonomy is a complex term, some scholars have tried to conceptualise it by focusing on what autonomy is not (Benson, 2001; Dam, 1995; Little, 1991). Little (1991), for instance, asserts that learner autonomy does not just mean self-instruction without any outside help from a teacher or a tutor. Moreover, it is not only about out-of-class learning (Benson, 2001), but it is also exercised in the classroom environment (Dam, 1995). Therefore, it is reasonable to conclude from these studies that autonomy is not learning without a teacher but it requires teachers and learners to work collaboratively. Moreover, understanding autonomy has a lot to do with understanding learning experiences. Investigating previous experiences is important because as Cotterall (1995) asserts, "learner confidence goes hand in hand with a belief in one's ability to influence the outcome of learning and derives from perceptions of previous learning experiences" (p. 201). These perceptions affect the understanding of the autonomy and have an effect on future behaviours.

Language teachers are one of the stakeholders who are responsible for fostering EFL learners' learner autonomy. In line with this, Holec (1981) argues that the "ability to take charge of one's own learning" (p. 3) is not necessarily inborn; on the contrary, someone needs to acquire it by natural means or by formal learning. Having a sense of autonomy can be one of the 
characteristics of effective teachers because an effective teacher should foster autonomous behaviour (Balçıkanl1, 2009). In order to be successful in teaching, including in facilitating the development of learners' learner autonomy, teachers need to be autonomous themselves. As Little (1995) points out:

"[S]uccessful learners have always been autonomous. The same is true of teacher autonomy. Genuinely successful teachers have always been autonomous in the sense of having a strong sense of personal responsibility for their teaching, exercising via continuous reflection and analysis the highest possible degree of affective and cognitive control of the teaching process, and exploiting the freedom that this confers" (p. 179).

The quality of pre-service teacher training is a decisive factor in the development of teacher autonomy (Castle, 2004), which is studied with diverse variables such as teachers' perspectives (Garvin, 2007), the environments regarding the work (Pearson \& Moomaw, 2006), decision making processes (Friedman, 1999), and curriculum development (Dymoke \& Harrison, 2006). Therefore, understanding the student teachers' perspectives regarding the environment they will work in and their decision-making processes are important to observe their readiness for teacher autonomy. Teacher autonomy is a prerequisite for the development of learner autonomy (Little, 1995). The quality of teacher education program with regard to the practicing of learner autonomy plays a role on teacher autonomy as well. Decision making process as a variable is directly related to entailing the concept of choice and this can be achieved by practicing autonomy in teacher education programs. In other words, the earlier language teachers are introduced with the concept and principles of autonomy in their initial teacher training, the more likely they are strong enough to foster it in their future students.

In the context of fostering autonomy in English language classes, preparing teachers to promote learner autonomy in SLTE programs is therefore of paramount importance. Pre-service teacher education can be regarded as a venue to teach student teachers to become autonomous and to learn how to promote their students' autonomy. Language teachers need to develop autonomous skills in their pre-service teacher education so that they can develop positive attitudes towards the development of learner autonomy in their own teaching (Balçıkanl1, 2010). However, it is also suggested that it would be difficult for language teachers to use the tools of autonomous learning (e.g., responsibilities, skills, motivation, and involving students in the 
teaching process and choosing activities that increase interest and motivation) effectively if they were trained within an education system that had not fostered autonomy (Erdoğan, 2003; Sert, 2006). In other words, "language teachers without any autonomy-oriented training may experience difficulties in creating such a classroom culture" (Balçıkanlı, 2010, p. 91). Hence, ELT student teachers need to be engaged in autonomous learning in their education. It is only after this can they develop positive attitudes towards the development of the autonomy of their future students.

Numerous studies have investigated Turkish EFL learners' readiness for learner autonomy (Balçıkanlı, 2010; Karabıyık, 2008; Sert, 2006; Yıldırım, 2005). However, there is a need to investigate the culture of learning in which ELT student teachers are educated because learner autonomy does not develop spontaneously within the learner, but rather, it develops out of the learner's interaction with the outside world (Cotteral, 1995), and it cannot be reached overnight (Bertoldi, Kollar, \&Ricard, 1988). Therefore, this study set out to investigate the student teachers' learning culture, their own readiness for learner autonomy, and their readiness to foster their future students' autonomy. Investigating the culture of learning in the high school and the culture of learning in the SLTE program is necessary because readiness for learner autonomy could provide guidance to decide further actions for stakeholders such as curriculum developers, material designers and adapters, classroom practitioners and teacher trainers (Ho \& Crookall, 1995; Little, 1995; Scharle \& Szabo, 2000). To this end, the specific research questions are as follows:

1. What kind of autonomous learning activities did Turkish EFL student teachers get engaged in during their high school education?

2. To what extent are Turkish EFL student teachers ready for autonomous language learning?

a. How do student teachers perceive their own and their teachers' responsibilities in the language learning process in their SLTE program?

b. What do they think about their decision-making abilities in foreign language learning in their SLTE program?

c. What kind of autonomous learning activities do they engage in inside and outside of the classroom in their SLTE program? What is the frequency of these activities? 


\section{METHOD}

This study followed a mixed method design in which quantitative data were collected via two kinds of questionnaires and qualitative data through semi-structured interviews with volunteer student teachers. The questionnaires examined autonomous learning activities of the participants in their high schools and in their SLTE program, their views on their own and their teachers' responsibilities, and their decision-making abilities in their SLTE program. Interviews were used to elicit in-depth data about their ideas in the questionnaires.

The participants were 110 fourth year pre-service students of an SLTE program at a public university in central Anatolia, Turkey. There were 120 student teachers enrolled in the program. The researchers could not reach ten student teachers as they were absent while the study was ongoing and they did not volunteer to participate later. In this four-year language teacher education program, the participants took language skills courses such as lexicology, grammar, reading, listening and pronunciation, speaking and writing in their first year of education. They also took courses on introduction to education, and educational psychology. After the third semester, they took courses such as language acquisition, teaching of language skills, teaching English to young learners, language testing, and material development. Practicum courses (School Experience and Teaching Experience) were taken in the last year of the program. In School Experience, student teachers observe mentor teachers in real schools and take observational notes for their supervisors at the university. In Teaching Experience, on the other hand, they both observe and teach for at least eight hours in a semester and receive feedback from their mentor teachers and supervisors.

The data for the study came from two questionnaires and semi-structured interviews. While the first questionnaire examines the high school experiences of the participants regarding learner autonomy, the second questionnaire explores the autonomy levels of the participants in their SLTE program. The first questionnaire, Culture of Learning Questionnaire, was developed by Karabiyık (2008). There were 13 questions in the questionnaire. The first question aimed to investigate the participants' views about the general role of the language teachers in their high schools. They were asked to rate it on a five-point Likert scale ranging from ' 1 ', representing the sole authority, to ' 5 ', representing facilitator. The second question aimed to see participants' 
perceptions about their role as a learner in their high school also on a five-point Likert scale, ranging from ' 1 ', representing teacher dependent to '5', representing autonomous. In the rest of the questions, from no. 3 to 13 , the student teachers were asked to mention the frequency of autonomous learning activities they were engaged in during their high school education on a fourpoint Likert ranging from 'never' to 'frequently.'

The second questionnaire, Learner Autonomy Readiness Questionnaire, was originally developed by Chan, Spratt, and Humphreys (2002) in order to investigate the readiness of tertiary Hong Kong students for learner autonomy. The questionnaire was translated into different languages and adapted to different contexts. In this study, the adapted version by Karabıyık (2008) was used. In the original questionnaire, there were 42 items and three sections. In the first section of this five-point Likert scale, the students were asked to assess their own and their teachers' responsibilities in the language learning process. In section two, students' perceptions of their abilities to act autonomously were inquired, whereas section three focused on students' actual practices of autonomous learning activities outside the classroom. The quantitative data obtained from the questionnaires were analyzed through descriptive statistics (frequency, percentages, mean, and standard deviation).

In addition to the questionnaires, semi-structured interviews with 23 of the participants were conducted. Semi-structured interviews, which can be considered between structured and unstructured interviews, allow a greater flexibility regarding the organization of questions and allow for substantial follow-up responses (Dörnyei, 2007). In the interviews done in this study, besides some pre-determined questions, an open-ended format is followed and the raised issues can be elaborated. The interviews were conducted to deeply understand the views, beliefs, and actions of the participants. All of the interviewees were volunteers and each interview lasted approximately 20 minutes.

The pre-determined questions in the interview were: 1) What are your beliefs about good language learning?; 2) What does a good language learner do or have?; 3) What should be the roles of teachers and learners in the language classrooms?; 4) Did the teaching and learning environment in your high school help or hinder the development of autonomy? In what ways?; 5) Does the teaching and learning environment at your university (in the ELT program) help or hinder the development of autonomy? In what ways?; 6) Did you prepare any portfolios in your high school or university?; 7) What did you 
do for your English when you were in high school and at the university?; 8) In what ways do you compare your high school and university education?; 9) How do you perceive yourself as a teacher to promote your learners' autonomy?; 10) Do you know how to help your learners foster their autonomy?

The qualitative data gathered through the semi-structured interviews were subjected to content analysis. According to Cresswell (2012), early data analysis requires information organization and the transfer of spoken and written information to a typed file. Hence, the audio-recorded data were transcribed, and content analysis was conducted. Following the data analyses procedure suggested by Cresswell (2012) and Patton (2014), the data were intensively read to find themes and patterns (pattern recognition) and analysed inductively to find patterns, themes, and categories. Then data reduction was conducted focusing on the research questions. Last, the data were interpreted to reach generalizations and relate them to literature.

\section{FINDINGS AND DISCUSSION}

\section{Findings}

The findings from the study are presented in three folds: a) the student teachers' culture of learning (student teachers' perceptions of their teachers' role in high school and autonomous learning activities that the student teachers engaged in when they were in their high schools), b) their readiness as learners in the SLTE program (perceptions of their own and their teachers' responsibilities, decision-making abilities, and engagement in autonomous activities outside and in the class), and c) their readiness as teacher candidates in promoting their future students' learning autonomy.

\section{Questionnaire Results}

The findings related to participants' language learning culture, referring to the earlier autonomous learning activities the student teachers got engaged in during their high school education, provide details about the student teachers' perceptions of their own roles and their language teachers' role for the development of learner autonomy. The first question of the questionnaire investigates the perceived general teacher profile in high schools. The results are shown in Table 1. 
Kartal \& Balçıkanlı, Tracking the Culture of Learning and Readiness for LA 29

Table 1. Student Teachers' Perceptions of their Teachers' Role in High School

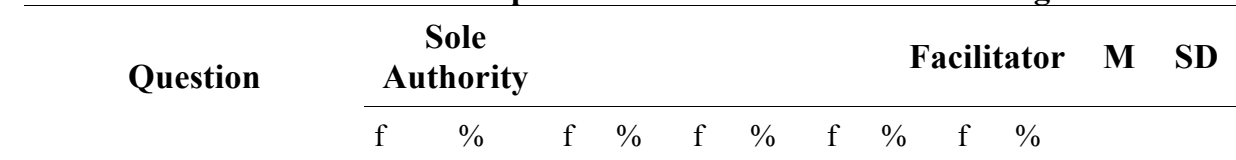

1. Considering the general teacher profile in $\begin{array}{llllllllllllll}\text { the high school you } & 8 & 9.4 & 10 & 11.8 & 28 & 32.9 & 28 & 32.9 & 11 & 12.9 & 3.28 & 1.13\end{array}$ graduated from, how would you define the role of your teachers in class?

Note: Out of 110 participants, there were 25 units of missing data for the first question (Valid N: 85)

The results in Table 1 indicate that the teachers were neither the sole authority nor the fully facilitator. In other words, considering the general language teacher profile in the high school the participants graduated from, they do not see the teachers either as the sole authority or a full facilitator. The findings about the roles of the participants are illustrated in Table 2.

Table 2. Student Teachers' Perceptions of Their Own Roles in High School

\begin{tabular}{|c|c|c|c|c|c|c|c|c|c|}
\hline \multirow{2}{*}{ Question } & \multicolumn{3}{|c|}{$\begin{array}{c}\text { Teacher- } \\
\text { Dependent }\end{array}$} & \multicolumn{4}{|c|}{ Autonomous } & \multirow[b]{2}{*}{ M } & \multirow[b]{2}{*}{ SD } \\
\hline & $\mathrm{f}$ & $\%$ & $\mathrm{f} \quad \% \quad \mathrm{f}$ & $\%$ & f $\%$ & $\mathrm{f}$ & $\%$ & & \\
\hline $\begin{array}{l}\text { 2. How would you define your } \\
\text { role as a learner when you were in } \\
\text { the high school? }\end{array}$ & 0 & 0 & $\begin{array}{lll}12 & 14 & 19\end{array}$ & 22.1 & 3641.9 & 19 & 22.1 & 3.72 & .966 \\
\hline
\end{tabular}

Table 2 shows that the participants were not completely autonomous or teacher-dependent. However, they believed their role was closer to autonomous than to teacher-dependent.

In order to see the general picture of the frequency of autonomous learning activities that the participants engaged in, mean score and standard deviations were computed (Table 3). 
30 TEFLIN Journal, Volume 30, Number 1, January 2019

Table 3. Autonomous Learning Activities that the Student Teachers Engaged in Their High Schools

\begin{tabular}{|c|c|c|c|c|c|c|c|c|c|c|}
\hline \multirow[b]{2}{*}{$\begin{array}{l}\text { Throughout your high school } \\
\text { education, }\end{array}$} & \multicolumn{2}{|c|}{ Never } & \multicolumn{2}{|c|}{ Rarely } & \multicolumn{2}{|c|}{ Sometimes } & \multicolumn{2}{|c|}{ Frequently } & \multirow{2}{*}{ M } & \multirow{2}{*}{ SD } \\
\hline & f & $\%$ & f & $\%$ & f & $\%$ & f & $\%$ & & \\
\hline $\begin{array}{l}\text { 3. How often were you asked } \\
\text { to participate in group/pair } \\
\text { work activities? }\end{array}$ & 5 & 4.6 & 22 & 20.2 & 45 & 41.3 & 37 & 33.9 & 3.05 & .854 \\
\hline
\end{tabular}

$\begin{array}{lllllllllll}\text { 4. How often were you asked } & 14 & 12.7 & 33 & 30 & 40 & 36.4 & 23 & 20.9 & 2.65 & .952\end{array}$ to evaluate your own work?

\begin{tabular}{lcccccccccc}
\hline $\begin{array}{l}\text { 5. How often were you asked } \\
\text { to evaluate your peers' work? }\end{array}$ & 21 & 19.3 & 33 & 30.3 & 41 & 37.6 & 14 & 12.8 & 2.44 & .947 \\
\hline $\begin{array}{l}\text { 6. How often were you asked } \\
\text { to choose your partners that } \\
\text { you wanted to work with? }\end{array}$ & 8 & 7.3 & 14 & 12.7 & 37 & 33.6 & 51 & 46.4 & 3.19 & .924 \\
\hline $\begin{array}{l}\text { 7. How often were you asked } \\
\text { to participate in a project } \\
\text { work? }\end{array}$ & 10 & 9.3 & 25 & 23.1 & 47 & 43.5 & 26 & 24.1 & 2.82 & .905 \\
\hline
\end{tabular}

\begin{tabular}{lllllllllll}
\hline 8. How often did your teachers & 21 & 19.3 & 36 & 33 & 38 & 34.9 & 14 & 12.8 & 2.41 & .945
\end{tabular} ask you to choose what activities to use in your lessons?

$\begin{array}{lllllllllll}\text { 9. How often did your teachers } & 29 & 26.6 & 32 & 29.4 & 38 & 34.9 & 10 & 9.2 & 2.27 & .959\end{array}$ ask you to choose what materials to use in your lessons?

$\begin{array}{lllllllllll}\text { 10. How often were you asked } & 16 & 14.7 & 23 & 21.1 & 44 & 40.4 & 26 & 23.9 & 2.73 & .987\end{array}$ to set your own learning goals?

$\begin{array}{lllllllllll}\text { 11. How often were you asked } & 16 & 15 & 36 & 33.6 & 33 & 30.8 & 22 & 20.6 & 2.57 & .982\end{array}$ to evaluate your course?

$\begin{array}{lllllllllll}\text { 12. How often were you asked } & 23 & 21.3 & 43 & 39.8 & 34 & 31.5 & 8 & 7.4 & 2.25 & .887\end{array}$ to decide what you should learn next?

$\begin{array}{lllllllllll}\text { 13. How often were you asked } & 45 & 41.3 & 27 & 24.8 & 20 & 18.3 & 17 & 15.6 & 2.08 & 1.107\end{array}$ to prepare portfolios?

N: 110 
Kartal \& Balçıkanll, Tracking the Culture of Learning and Readiness for LA 31

The results in Table 3 show that participants rarely got engaged in autonomous learning activities in their high schools, which means that the average participants started to study at university without having been exposed to autonomous learning activities. The items that were most commonly mentioned were choosing partners to work with, being asked to participate in group/pair work activities and being asked to participate in a project work.

The second questionnaire in the study, the Learner Autonomy Readiness Questionnaire was used to explore the participants' own autonomy levels related to their experiences during the SLTE program which they enrolled in. This section thus presents the findings related to the second research question and its sub-questions. Firstly, student teachers' perceptions of their and their teachers' responsibilities in the SLTE program have been investigated (see Table 4).

Table 4. Perceptions of their Own and their Teachers' Responsibilities

\begin{tabular}{|c|c|c|c|c|c|c|c|c|c|c|c|c|}
\hline \multirow[t]{2}{*}{$\begin{array}{l}\text { In English lessons, whose } \\
\text { responsibility should it be } \\
\text { to, }\end{array}$} & \multicolumn{2}{|c|}{$\begin{array}{c}\text { Completely } \\
\text { the } \\
\text { teacher's }\end{array}$} & \multicolumn{2}{|c|}{$\begin{array}{l}\text { Mostly } \\
\text { the } \\
\text { teacher's, } \\
\text { partly } \\
\text { mine }\end{array}$} & \multicolumn{2}{|c|}{$\begin{array}{c}\text { Half } \\
\text { mine, } \\
\text { half the } \\
\text { teacher's }\end{array}$} & \multicolumn{2}{|c|}{$\begin{array}{c}\text { Mostly } \\
\text { mine, } \\
\text { partly } \\
\text { the } \\
\text { teacher's }\end{array}$} & \multicolumn{2}{|c|}{$\begin{array}{l}\text { Completely } \\
\text { mine }\end{array}$} & \multirow[t]{2}{*}{$\mathbf{M}$} & \multirow[t]{2}{*}{ SD } \\
\hline & $\mathbf{f}$ & $\%$ & f & $\%$ & f & $\%$ & f & $\%$ & f & $\%$ & & \\
\hline $\begin{array}{l}\text { 14. make sure you make } \\
\text { progress during lessons }\end{array}$ & 4 & 3.7 & 13 & 11.9 & 45 & 41.3 & 38 & 34.9 & 9 & 8.3 & 3.32 & .922 \\
\hline $\begin{array}{l}\text { 15. make sure you make } \\
\text { progress outside the class }\end{array}$ & 3 & 2.7 & 2 & 1.8 & 13 & 11.8 & 30 & 27.3 & 62 & 56.4 & 4.33 & .949 \\
\hline $\begin{array}{l}\text { 16. stimulate your interest } \\
\text { in learning English }\end{array}$ & 4 & 3.7 & 14 & 12.8 & 24 & 22 & 30 & 27.5 & 37 & 33.9 & 3.75 & 1.164 \\
\hline $\begin{array}{l}\text { 17. identify your } \\
\text { weaknesses in English }\end{array}$ & 5 & 4.5 & 8 & 7.3 & 28 & 25.5 & 33 & 30 & 36 & 32.7 & 3.79 & 1.118 \\
\hline 18. make you work harder & 3 & 2.7 & 7 & 6.4 & 13 & 11.8 & 33 & 30 & 54 & 49.1 & 4.16 & 1.045 \\
\hline $\begin{array}{l}\text { 19. decide the objectives of } \\
\text { the English course }\end{array}$ & 14 & 12.8 & 13 & 11.9 & 29 & 26.6 & 29 & 26.6 & 24 & 22 & 3.33 & 1.299 \\
\hline $\begin{array}{l}\text { 20. decide what you should } \\
\text { learn next }\end{array}$ & 21 & 19.3 & 29 & 26.6 & 31 & 28.4 & 18 & 16.5 & 10 & 9.2 & 2.70 & 1.221 \\
\hline
\end{tabular}


32 TEFLIN Journal, Volume 30, Number 1, January 2019

\begin{tabular}{|c|c|c|c|c|c|c|c|c|c|c|c|c|}
\hline \multirow[t]{2}{*}{$\begin{array}{l}\text { In English lessons, whose } \\
\text { responsibility should it be } \\
\text { to, }\end{array}$} & \multicolumn{2}{|c|}{$\begin{array}{c}\text { Completely } \\
\text { the } \\
\text { teacher's }\end{array}$} & \multicolumn{2}{|c|}{$\begin{array}{c}\text { Mostly } \\
\text { the } \\
\text { teacher's, } \\
\text { partly } \\
\text { mine }\end{array}$} & \multicolumn{2}{|c|}{$\begin{array}{c}\text { Half } \\
\text { mine, } \\
\text { half the } \\
\text { teacher's }\end{array}$} & \multicolumn{2}{|c|}{$\begin{array}{l}\text { Mostly } \\
\text { mine, } \\
\text { partly } \\
\text { the } \\
\text { teacher's }\end{array}$} & \multicolumn{2}{|c|}{$\begin{array}{l}\text { Completely } \\
\text { mine }\end{array}$} & \multirow[t]{2}{*}{ M } & \multirow[t]{2}{*}{ SD } \\
\hline & f & $\%$ & f & $\%$ & f & $\%$ & f & $\%$ & f & $\%$ & & \\
\hline $\begin{array}{l}\text { 21. choose what activities } \\
\text { to use in your English } \\
\text { lessons }\end{array}$ & 18 & 16.4 & 29 & 26.4 & 40 & 36.4 & 17 & 15.5 & 6 & 5.5 & 2.67 & 1.093 \\
\hline $\begin{array}{l}\text { 22. decide how long to } \\
\text { spend on each activity }\end{array}$ & 32 & 29.1 & 34 & 30.9 & 23 & 20.9 & 13 & 11.8 & 8 & 7.3 & 2.37 & 1.226 \\
\hline $\begin{array}{l}\text { 23. choose what materials } \\
\text { to use in your English } \\
\text { lessons }\end{array}$ & 17 & 15.5 & 35 & 31.8 & 33 & 30 & 15 & 13.6 & 10 & 9.1 & 2.69 & 1.163 \\
\hline 24. evaluate your learning & 24 & 21.8 & 23 & 20.9 & 35 & 31.8 & 17 & 15.5 & 11 & 10 & 2.71 & 1.251 \\
\hline 25. evaluate your course & 19 & 17.3 & 31 & 28.2 & 37 & 33.6 & 14 & 12.7 & 9 & 8.2 & 2.66 & 1.152 \\
\hline $\begin{array}{l}\text { 26. decide what you learn } \\
\text { outside the class }\end{array}$ & 5 & 4.5 & 6 & 5.5 & 14 & 12.7 & 25 & 22.7 & 60 & 54.5 & 4.17 & 1.132 \\
\hline
\end{tabular}

Table 4 shows that making progress outside the class, working harder, and deciding what to learn outside the class are mostly the students' responsibility as mentioned by the participants. On the other hand, deciding how long to spend on each activity and evaluating the course are mostly the teachers' responsibility. Although participants are willing to take responsibility for certain areas of their learning within the classroom, they give the responsibility to the teacher, especially learning outside the class.

The activities that the participants rated themselves as close to 'very good' in terms of decision-making in the class, according to the mean scores, are choosing learning activities outside the class, evaluating their courses, identifying weaknesses in learning English, choosing learning materials outside the class, and choosing learning objectives outside the class. This is presented in more details in Table 5. 
Kartal \& Balçıkanll, Tracking the Culture of Learning and Readiness for LA 33

Table 5. Decision-Making Abilities

\begin{tabular}{|c|c|c|c|c|c|c|c|c|c|c|c|c|}
\hline \multirow{2}{*}{$\begin{array}{l}\text { How do you think you } \\
\text { would be at: }\end{array}$} & \multicolumn{2}{|c|}{$\begin{array}{l}\text { Very } \\
\text { Poor }\end{array}$} & \multicolumn{2}{|c|}{ Poor } & \multicolumn{2}{|c|}{ OK } & \multicolumn{2}{|c|}{ Good } & \multicolumn{2}{|c|}{$\begin{array}{l}\text { Very } \\
\text { good }\end{array}$} & \multirow[t]{2}{*}{$\mathbf{M}$} & \multirow[t]{2}{*}{ SD } \\
\hline & $\mathbf{f}$ & $\%$ & f & $\%$ & f & $\%$ & f & $\%$ & f & $\%$ & & \\
\hline $\begin{array}{l}\text { 27. choosing learning } \\
\text { activities in class? }\end{array}$ & 3 & 2.7 & 5 & 4.5 & 38 & 34.5 & 44 & 40 & 20 & 18.2 & 3.66 & .911 \\
\hline $\begin{array}{l}\text { 28. choosing learning } \\
\text { activities outside class? }\end{array}$ & 3 & 2.7 & 3 & 2.7 & 28 & 25.5 & 42 & 38.2 & 34 & 30.9 & 3.92 & .959 \\
\hline $\begin{array}{l}\text { 29. choosing learning } \\
\text { objectives in the class? }\end{array}$ & 1 & 0.9 & 5 & 4.5 & 41 & 37.3 & 49 & 44.5 & 14 & 12.7 & 3.64 & .798 \\
\hline $\begin{array}{l}\text { 30. choosing learning } \\
\text { objectives outside the } \\
\text { class? }\end{array}$ & 0 & 0 & 6 & 5.5 & 35 & 31.8 & 36 & 32.7 & 33 & 30 & 3.87 & .910 \\
\hline $\begin{array}{l}\text { 31.choosing learning } \\
\text { materials in the class? }\end{array}$ & 1 & .9 & 6 & 5.5 & 43 & 39.1 & 40 & 36.4 & 20 & 18.2 & 3.65 & .872 \\
\hline $\begin{array}{l}\text { 32. choosing learning } \\
\text { materials outside the } \\
\text { class? }\end{array}$ & 0 & 0 & 5 & 4.5 & 33 & 30 & 41 & 37.3 & 31 & 28.2 & 3.89 & .871 \\
\hline $\begin{array}{l}\text { 33. evaluating your } \\
\text { learning? }\end{array}$ & 0 & 0 & 3 & 2.7 & 38 & 34.5 & 49 & 44.5 & 20 & 18.2 & 3.78 & .771 \\
\hline $\begin{array}{l}\text { 34. evaluating your } \\
\text { course? }\end{array}$ & 0 & 0 & 4 & 3.6 & 27 & 24.5 & 62 & 56.4 & 17 & 15.5 & 3.84 & .723 \\
\hline $\begin{array}{l}35 . \text { identifying your } \\
\text { weaknesses in learning } \\
\text { English? }\end{array}$ & 0 & 0 & 3 & 2.7 & 26 & 23.6 & 51 & 46.4 & 30 & 27.3 & 3.98 & .790 \\
\hline $\begin{array}{l}\text { 36. deciding what you } \\
\text { should learn next in your } \\
\text { English lessons? }\end{array}$ & 2 & 1.8 & 8 & 7.3 & 37 & 33.6 & 45 & 40.9 & 18 & 16.4 & 3.63 & .907 \\
\hline
\end{tabular}

The third part of the "Readiness for Learner Autonomy Questionnaire" is related to the autonomous language learning activities that participants carried out outside the class during their SLTE program. The mean scores in Table 6 show that except for some activities (watching English movies, listening to English songs, watching English TV programs), the participants did not frequently get engaged in out-of-class autonomous activities. 
34 TEFLIN Journal, Volume 30, Number 1, January 2019

Table 6. Engagement in Autonomous Activities outside the Class

\begin{tabular}{|c|c|c|c|c|c|c|c|c|c|c|}
\hline \multirow{2}{*}{$\begin{array}{l}\text { In your BA, outside of class, } \\
\text { without having been } \\
\text { assigned to do so, how often } \\
\text { did you: }\end{array}$} & \multicolumn{2}{|c|}{ Never } & \multicolumn{2}{|c|}{ Rarely } & \multicolumn{2}{|c|}{ Sometimes } & \multicolumn{2}{|c|}{ Often } & \multirow[t]{2}{*}{$\mathbf{M}$} & \multirow[t]{2}{*}{ SD } \\
\hline & $\mathbf{f}$ & $\%$ & f & $\%$ & $\mathbf{f}$ & $\%$ & $\mathbf{f}$ & $\%$ & & \\
\hline $\begin{array}{l}\text { 38. read grammar books on } \\
\text { your own? }\end{array}$ & 18 & 16.5 & 35 & 32.1 & 36 & 33 & 20 & 18.3 & 2.53 & .977 \\
\hline $\begin{array}{l}\text { 39. note down new words and } \\
\text { their meanings? }\end{array}$ & 9 & 8.2 & 21 & 19.1 & 47 & 42.7 & 33 & 30 & 2.95 & .907 \\
\hline $\begin{array}{l}\text { 40. send letters to your pen- } \\
\text { friends? }\end{array}$ & 50 & 45.5 & 27 & 24.5 & 21 & 19.1 & 12 & 10.9 & 1.95 & 1.044 \\
\hline $\begin{array}{l}\text { 41. read newspapers in } \\
\text { English? }\end{array}$ & 16 & 14.5 & 36 & 32.7 & 44 & 40 & 14 & 12.7 & 2.51 & .896 \\
\hline 42. send e-mails in English? & 23 & 20.9 & 26 & 23.6 & 35 & 31.8 & 26 & 23.6 & 2.58 & 1.070 \\
\hline $\begin{array}{l}\text { 43. read books or magazines } \\
\text { in English? }\end{array}$ & 8 & 7.3 & 20 & 18.2 & 50 & 45.5 & 32 & 29.1 & 2.96 & .877 \\
\hline $\begin{array}{l}\text { 44. watch English TV } \\
\text { programs? }\end{array}$ & 5 & 4.5 & 12 & 10.9 & 37 & 33.6 & 56 & 50.9 & 3.31 & .843 \\
\hline 45. listen to English radio? & 18 & 16.4 & 23 & 20.9 & 38 & 34.5 & 31 & 28.2 & 2.75 & 1.044 \\
\hline 46. listen to English songs? & 3 & 2.7 & 11 & 10 & 33 & 30 & 63 & 57.3 & 3.42 & .783 \\
\hline $\begin{array}{l}\text { 47. speak English with native } \\
\text { speakers? }\end{array}$ & 10 & 9.5 & 28 & 25.5 & 41 & 37.3 & 31 & 28.2 & 2.85 & .940 \\
\hline $\begin{array}{l}\text { 48. practice using English } \\
\text { with friends? }\end{array}$ & 9 & 8.2 & 44 & 40 & 35 & 31.8 & 22 & 20 & 2.64 & .896 \\
\hline 49. watch English movies? & 7 & 6.4 & 11 & 10 & 31 & 28.2 & 61 & 55.5 & 3.33 & .900 \\
\hline 50. write a diary in English? & 58 & 52.7 & 21 & 19.1 & 17 & 15.5 & 14 & 12.7 & 1.88 & 1.090 \\
\hline $\begin{array}{l}\text { 51. use the Internet in } \\
\text { English? }\end{array}$ & 15 & 13.8 & 19 & 17.4 & 34 & 31.2 & 41 & 37.6 & 2.93 & 1.052 \\
\hline $\begin{array}{l}\text { 52. review your written work } \\
\text { on your own? }\end{array}$ & 24 & 22 & 28 & 25.7 & 36 & 33 & 21 & 19.3 & 2.50 & 1.042 \\
\hline 53. attend a self-study centre? & 41 & 37.6 & 33 & 30.3 & 26 & 23.9 & 9 & 8.3 & 2.03 & .976 \\
\hline $\begin{array}{l}54 . \text { talk to your teacher about } \\
\text { your work? }\end{array}$ & 24 & 22.2 & 34 & 31.5 & 35 & 32.4 & 15 & 13.9 & 2.38 & .983 \\
\hline
\end{tabular}


Table 7 shows the participants' engagement in autonomous activities in their classes at the SLTE program. The findings show that the percentages of the participants' involvement in autonomous activities in the class were considerably low compared to the percentages in the out-of-class activities in Table 6. In other words, the mean scores of in-class activities are lower than some of the outside classroom activities. The out-of-class activities that are most frequently done by the student teachers are listening to English songs and watching English movies or TV programs. This might relate to the fact that they like to be involved in real-life activities while the classroom activities might be seen as artificial and they can be boring for some student teachers.

Table 7. Engagement in Autonomous Activities in Class

\begin{tabular}{lccccccccccc}
\hline $\begin{array}{l}\text { In your BA, in class, how } \\
\text { often did you: }\end{array}$ & \multicolumn{2}{c}{ Never } & \multicolumn{2}{c}{ Rarely } & Sometimes & Often & M & SD \\
\cline { 2 - 12 } & $\mathbf{f}$ & $\mathbf{\%}$ & $\mathbf{f}$ & $\mathbf{\%}$ & $\mathbf{f}$ & $\mathbf{\%}$ & $\mathbf{f}$ & $\mathbf{\%}$ & & \\
\hline $\begin{array}{l}\text { 55. ask the teacher } \\
\text { questions when you do not } \\
\text { understand? }\end{array}$ & 5 & 4.6 & 39 & 35.8 & 26 & 23.9 & 39 & 35.8 & 2.91 & .948 \\
\hline $\begin{array}{l}\text { 56. make suggestions to } \\
\text { the teacher? }\end{array}$ & 24 & 22 & 34 & 31.2 & 29 & 26.6 & 22 & 20.2 & 2.45 & 1.050 \\
\hline $\begin{array}{l}\text { 57. take opportunities to } \\
\text { speak English? }\end{array}$ & 5 & 4.6 & 32 & 29.6 & 45 & 41.7 & 26 & 24.1 & 2.85 & .841 \\
\hline
\end{tabular}

The student teachers' readiness for promoting their future students' learning autonomy was tracked in the interview data. The interview findings provide insights into participants' culture of learning, readiness as students, and readiness as teacher candidates in promoting their future students' learning autonomy.

\section{Interview Results}

In order to provide a deeper analysis of the beliefs, opinions, and actions of the participants, 23 semi-structured interviews were conducted with volunteer student teachers. The findings are illustrated regarding the questions in the interview. Concerning the questions, "What are your beliefs about good language learning? What does a good language learner do or have?", most of the student teachers said that good language learners should be confident of 
their abilities to learn English well and should have a strong willingness and motivation to learn. The following comments can be given as representative answers:

"A good language learner is confident, searches everything, tries to find different sources, and also writes down new words s/he learns."

"A good language learner listens and speaks. S/he tries to understand English wherever s/he may be and whatever the circumstances may be."

In relation to the question "What should be the roles of teachers and learners in the language classrooms?", it can be said that student teachers view teachers' roles as they should be in an autonomous classroom environment. The voiced opinions show that the student teachers believe in the importance of teachers for learner autonomy. They understand that autonomy does not refer to learning without a teacher. Moreover, they support the view that teacher and learner roles should be shared. Teachers should be facilitators and learners should be active in decision-making processes. Here are two sample opinions of the student teachers:

"Students should not depend on teachers for everything. Of course, the role of the teachers and their responsibility is important, but teachers need to take students' needs into consideration."

"Our teachers were the sole authority in our high school. I graduated from general high school. The teachers just told us the names of the materials to study for the university entrance exam. Language teachers should be a guide but not in this way."

As for the question "Did the teaching and learning environment in your high school help or hinder the development of autonomy? In what ways?" the participants' responses in the interviews for this question yielded somewhat conflicting results regarding being able to choose materials or not. While some of the participants seem to experience freedom to choose among some options, the options they were given were limited and not allowing them to be fully autonomous.

"Teachers gave us the opportunity to choose. They allowed us to choose the materials, but those materials were only related to preparation tests for the university entrance exam."

"Everything was pre-determined. The classroom design was unfit to allow the teacher to do the job truly. I was in the USA in elementary and middle school. There they had round tables to make group work easier. There was also a rug in 
the class for different activities. In the high school in Turkey, the classroom environment was not suitable for autonomy."

"The teachers allowed us to choose materials and activities, but they were only about grammar and reading."

In response to the question, "Does the teaching and learning environment at your university (in the ELT program) help or hinder the development of autonomy? In what ways?", the participants believe that their experiences in the SLTE program were better than the high school considering the appropriateness of the learning environment to help develop autonomy. However, the SLTE was also not satisfactorily contributing to learner autonomy, such as, in terms of encouraging them to use the resources they have to improve their learning. Here are the opinions:

"I do not think it helps the development of autonomy. However, it is better than high school."

"I use my cell-phone in English. I love English, but in this program, I did not want to do anything. The program did not increase my motivation."

The next questions in the interview were, "Did you prepare any portfolios in your high school or university? What did you do for your English when you were in the high school and at the university" The aim of asking a question about portfolios was understanding whether the participants had a portfoliobased autonomous organization of the class. This was important to understand their autonomous learning experiences. The answers show that they were not involved in a portfolio-based language learning both in the high school and in the SLTE program. The answers also show that they had a simple understanding of portfolios as they believed that having a collection of test books can be considered as a portfolio. The following answers are a summary of the student teachers' views regarding this:

"We did not prepare portfolios in high school; we never talked in English, we only worked with multiple-choice tests. At the university, we prepared portfolios a few times."

"In my high school, I did not prepare any portfolios during my education. Teachers prepared us for the university entrance exam. We did lots of grammar and reading in high school. At the university, we did not speak or write English. My reading and grammar have worsened because of it."

Another question in the interview: "In what ways do you compare your high school and university education", aimed at allowing the interviewees to 
add anything they wanted to express or found important. The extracts below indicate the issue regarding the national test students have to take in Turkey, which focuses on reading, vocabulary, and grammar, while excluding listening, speaking and writing. This situation affected the contents of the English teaching in high school as well as in the SLTE program. Here are the representative excerpts from the interview:

"I was in Germany in the high school. We focused on listening, writing, and speaking. However, at the university, the focus was on grammar, reading, and metalanguage."

"We used to choose materials and activities in the high school, but they were directly related to the university entrance exam. The professors did not ask our opinions in the ELT program."

A final question was asked to the student teachers to track their readiness to promote their future students' learning autonomy. The question was: "How do you perceive yourself as a teacher to promote your learners' autonomy and do you know how to help your learners foster their autonomy?" The answers indicate that they are not fully ready to promote learner autonomy among their future students, but they consider learner autonomy important and plan to take small steps to create an autonomy-supportive environment. The first quote below shows that the student teacher is planning to get help from his teachers trainers when he faces a problem. This indicates that the learner attaches significance to trainer support, which is good for his professional development. However, it can also be considered an issue of theory-practice gap. The first quotation shows that the student teacher is not planning to apply research findings but simply ask someone else for help, while the second quotation shows that the student teachers are not fully aware of the ways a teacher can help foster their students' learner autonomy.

"When I become a real teacher, I will ask some questions to my teacher trainers and then I will act accordingly. However, I will try to launch a conversation club in which my learners will practice the language. They need to be free and courageous to speak and to use the language."

"I am not sure about the things I can do for my learners to make them more autonomous but I will try to focus on listening and speaking instead of only grammar and reading. Also, I can try to design one of the classrooms as a language class in which learners can find some books and posters." 
Kartal \& Balçıkanl, Tracking the Culture of Learning and Readiness for LA 39

\section{Discussion}

This study tracked student teachers' previous engagement in autonomous learning in their high schools, investigated the readiness for learner autonomy, and examined their readiness to promote their future learners' autonomy. The findings supported the idea that the student teachers lack autonomy in language learning both in the high schools and at their teacher education program at the university. Although learner autonomy is one of the objectives of the current English language program (Balçıkanlı, 2010, Çakıcı, 2017; Yumuk, 2002), teacher-centered approaches are still dominant, which results in problems for teachers to have the desirability and feasibility to foster their students' autonomy (Chan, 2003; Keuk \& Heng, 2016). When the participants' learning experiences during high school and university education are compared, the participants experienced a more autonomous environment in the university than in high school. This confirms previous studies on Turkish EFL students' learner autonomy which show that Turkish students are lacking in autonomy and it interferes with the development of their language skills (Karabiyık, 2008; Koçak, 2003). Yumuk (2002) explains the situation in Turkey clearly.

"One of the main problems facing students entering university in Turkey is the prevailing view that the teacher is the dominant authority who controls learning, which contradicts the active role learners should take in academic contexts in order to process the flow of new information." (p. 152)

The findings revealed that learner autonomy is considered a vital part of learning by almost all respondents in the study (95\%) as also found in Chan, Spratt, and Humphreys' (2002) study, which investigated the readiness of Hong Kong students for learner autonomy. The student teachers also seem to have some definite ideas about the teacher and student roles inside and outside the classroom. In line with this, Ho and Crookall (1995) argue that autonomy requires not only independence from the teacher but also shared decisionmaking between the teacher and the students.

When the out-of-class activities are considered, the findings revealed that the student teachers mostly watched movies and listened to songs. Similar results were found by Okumuş-Ceylan (2014) for Turkish EFL learners. The fact that they did not really do other activities to support their English learning might be related to conditions they are in. For example, they may not simply have the opportunity for 'reading newspapers in English' or 'talking to 
foreigners in English.' This was congruent with Yıldırım's (2005) assumption that participants do not have access to these resources. Chan et al. (2002, p. 256) believe that "teachers seeking to promote autonomous behaviour in the form of outside-class activities may have more immediate success if they build on those that students already engage in, rather than on those activities which would require students to change their attitudes or behaviour" (p. 256). The student teachers then need to be encouraged to continue what they have been doing to improve their language proficiency. Apart from that, teacher trainers can further motivate and direct the student teachers to conduct some other similar activities outside the class, such as listening to podcasts, reading newspapers, and so on.

Another crucial issue is the finding related to the first research question which showed that student teachers consider themselves neither completely autonomous nor teacher dependent when they were in high school. They believed that their role was closer to being less teacher-dependent. However, a deeper analysis of the interviews revealed that student teachers' autonomy were pretty much limited to choosing test materials to study for their exam to enter university. The interviews also showed that the frequency of preparing portfolios in the high school was mainly about collecting exam-related materials (grammar books and examination tests) for self-study. It is reasonable to conclude that Turkish ELT student teachers are somewhat ready to be autonomous but the learning environment hinders them to fully utilize their autonomy for effective language learning.

In Turkey, teachers are reported to continue to use the grammartranslation method (Akalın \& Zengin, 2007; Büyükyavuz \& İnal, 2008; Oktay, 2015). One of the reasons to insist on this method is that it is considered the best route to success for the students in the university entrance exam in Turkey as students need to take a national university entrance exam and a Foreign Language Test (FLT). Reading, vocabulary, and grammar questions are tested in the FLT. In contrast, there is no national assessment done for listening, writing and speaking skills. The exam-oriented education policy in Turkey results in an obstacle not only to success in foreign language learning, especially success in productive skills but also to the development of learner autonomy both in the high school and at the SLTE program.

It is inaccurate, however, to conclude that Turkish ELT student teachers do not have the capacity for autonomy because they come from a teachercentred and exam-oriented culture of learning. Some of the student teachers 
involved in the study, for example, were found to be capable of working independently and as long as they were allowed to be autonomous and guided appropriately they could develop their autonomy further.

Curriculum design plays an important role to ensure students receive appropriate support and guidance to foster learner autonomy. In line with that, according to Benson (2001), learner involvement in a decision-making process begins at the level of curriculum, and it shows the importance of curriculum in an autonomous learning environment. In Turkey, the Council of Higher Education (CoHE) regulates the teacher education programs including SLTE programs. In 2018, CoHE published a new curriculum for teacher education programs in Turkey. CoHE has regulated all the compulsory and selective courses in the SLTE programs as well. On the other hand, one year prior to the new program by the CoHE, The Turkish Ministry of National Education (MoNE) reviewed its educational policy to redefine teacher competencies in line with the 21 st-century skills such as critical thinking, innovative production, effective communication, respect for cultural differences, and cooperation. MoNE has redefined general teacher competencies under three main components: 1) teacher knowledge, 2) teacher skills, and 3) attitude and values, which cannot be fulfilled without autonomous environments. Moreover, these teacher competencies should be considered in each program with all the stakeholders. If the CoHE and MoNE do not cooperate and provide the necessary support for the student teachers to develop an autonomous and selfdirected approach to learning in the SLTE programs, it is not likely that these teachers are able to promote the culture of learner autonomy among their future students. The change should begin with the SLTE programs and from there, it is strongly expected that the culture of learner autonomy would become widespread at every level of education.

\section{CONCLUSIONS}

This study explored fourth-year ELT student teachers' culture of learning, their readiness for learner autonomy, and their readiness as teacher candidates in promoting their students' learning autonomy. Even though the participants in this study had not started teaching English in real classes, it is important to investigate their readiness because it is evident in the literature that teachers can create a more suitable autonomous environment for their students only if they know their readiness for their own learner autonomy. 
In terms of culture of learning, it was found that the participants considered themselves to be less teacher-dependent during high school in a way that they have some autonomy in choosing learning materials. However, their freedom of choice seemed to be limited to exam-related materials. They also did not really engage in autonomous learning activities during high school. During the SLTE program, however, a lot of the participants are already practising some kind of autonomous activities (watching English movies and TV series, listening to English songs, using the Internet in English) outside the classroom, albeit rarely. Findings also show that student teachers are ready to take responsibility for their own language learning. Here, readiness means that they have satisfactory degrees of responsibility and this is a sign of motivation for future actions. Taking all these into consideration, since students do not become automatically autonomous in the classroom (Little, 1995), foreign language teachers in Turkey should try to foster their students' autonomy not only in universities but also in the high schools. Taken as a whole, it is revealed that even though student teachers of English are not fully ready for promoting learner autonomy of their future students, they consider learner autonomy important and plan to take small steps to create an autonomy-supportive environment.

The findings of the study imply the urgent need to foster learner autonomy among student teachers in SLTE programs in hope that they would be able to transfer the culture of learner autonomy that they have developed and experienced, among their future students. The findings also provide several further research directions. There is a need for more studies of learner autonomy in primary and secondary schools in Turkey. Future studies may consider observing the real classrooms and thus explore whether the autonomy is fostered in these classrooms or not. It is clearly stated in the literature that autonomy perceptions and practices are affected by contextual factors. Future studies may consider exploring detailed contextual factors on teachers' perceptions and in-class practices. Moreover, a case study can be conducted in a further study with different levels of students to get more detailed information about how learners perceive and practice autonomy in their learning. 
Kartal \& Balçıkanll, Tracking the Culture of Learning and Readiness for LA 43

\section{REFERENCES}

Akalın, S., \& Zengin, B. (2007). The attitude of people towards foreign language in Turkey. Journal of Language and Linguistics Studies, 3(1), 181-200.

Balçıkanl1, C. (2009, November). The European portfolio for student teachers of languages (EPOSTL): A journey to teacher autonomy. Paper presented at the International Conference for Academic Disciplines, Freiburg, Germany.

Balçıkanlı, C. (2010). Learner autonomy in language learning: student teachers' beliefs. Australian Journal of Teacher Education, 35(1), 89-103.

Baume, D. (1994). Developing learner autonomy. SEDA Paper 84. Birmingham, UK: Staff and Educational Development Association.

Benson, P. (2001). Teaching and researching autonomy in language learning. London: Longman.

Benson, P., \& Huang, J. (2008). Autonomy in the transition from foreign language learning to foreign language teaching. DELTA, 24, 421-439.

Bertoldi, E., Kollar, J., \& Ricard, E. (1988). Learning how to learn English: From awareness to action. ELT Journal, 42(3), 157-166.

Büyükyavuz O., \& İnal S. (2008). A descriptive study on Turkish teachers of English regarding their professional needs, efforts for development and available resources. Asian EFL Journal, 10(3), 215-234.

Castle, K. (2004). The meaning of autonomy in early childhood teacher education. Journal of Early Childhood Teacher Education, 25(1), 3-10.

Chan, V. (2003). Autonomous language learning: The teachers' perspectives. Teaching in Higher Education, 8(1), 33-54.

Chan, H. W. (2016). Popular culture, English out-of-class activities, and learner autonomy among highly proficient secondary students in Hong Kong. Universal Journal of Educational Research, 4(8), 1918-1923.

Chan, V., Spratt, M., \& Humphreys, G. (2002). Autonomous language learning: Hong Kong tertiary studentse attitudes and behaviours. Evaluation and Research in Education, 16(1), 1-18.

Cotterall, S. (1995). Readiness for autonomy: Investigating learner beliefs. System, 23(2), 195-205.

Cresswell, J. H. (2012). Educational research: Planning, conducting, and evaluating quantitative and qualitative research ( $4^{\text {th }}$ ed.) Boston: Pearson Education. 
Çakıc1, D. (2017). An investigation of learner autonomy in Turkish EFL Context. International Journal of Higher Education, 6(2), 89-99.

Dafei, D. (2007). An exploration of the relationship between learner autonomy and English proficiency. Asian EFL Journal, 24, 1-23.

Dam, L. (1995). Learner Autonomy 3: From theory to classroom practice. Dublin: Authentik.

Dörnyei, Z. (2007). Research methods in applied linguistics: Quantitative, qualitative and mixed mythologies. Oxford: Oxford University Press.

Dymoke, S., \& Harrison, J. K. (2006). Professional development and the beginning teacher: Issues of teacher autonomy and institutional conformity in the performance review process. Journal of Education for Teaching, 32(1), 71-92.

Erdoğan, S. (2003). Learner training via course books and teacher autonomy: A case of need. Retrieved from https://drive.google.com/file/d/0BwDvAVEemzNwODA3MDI0YzYtNTAxNy00 YWJiLTlmMTAtMTBmZGE1MDI3YmNm/view?ddrp=1\&hl=en

Field, J. (2007). Looking outwards, not inwards. ELT Journal, 61(1), 30-38

Friedman, I. A. (1999). Teacher perceived work autonomy: The concept and its measurement. Educational and Psychological Measurement, 59(1), 58-76.

Garvin, N. M. (2007). Teacher autonomy: Distinguishing perceptions by school cultural characteristics (Unpublished doctoral dissertation, University of Pennsylvania, Pennsylvania, USA).

Ho, J., \& Crookall, D. (1995). Breaking with Chinese cultural traditions: Learner autonomy in English language teaching. System, 23(2), 235-243.

Holec, H. (1981). Autonomy and foreign language learning. Oxford: Pergamon.

Illes, E. (2012). Learner autonomy revisited. ELT Journal, 66(4), 505-513.

Karabiyı, A. (2008). The relationship between culture of learning and Turkish university preparatory students' readiness for learner autonomy (Unpublished masters thesis, Bilkent University, Ankara, Turkey).

Keuk, C. N., \& Heng, V. (2016). Cambodian ELT teachers' beliefs and practices regarding language learner autonomy. In R. Barnard, \& J. Li (Eds.), Language learner autonomy: Teachers' beliefs and practices in Asian contexts (pp. 62-78). Phnom Penh: IDP Education.

Koçak, A. (2003). A study on learners' readiness for autonomous learning of English as a foreign language. (Unpublished masters thesis, Middle East Technical University, Ankara, Turkey). 
Kartal \& Balçıkanll, Tracking the Culture of Learning and Readiness for LA 45

Little, D. (1991). Learner autonomy 1: Definitions, issues and problems. Dublin: Authentik.

Little, D. (1995). Learning as dialogue: The dependence of learner autonomy on teacher autonomy. System, 23(2), 175-181.

Little, D. (2007). Language learner autonomy: Some fundamental considerations revisited. International Journal of Innovation in Language Learning and Teaching, 1(1), 14-29.

Little, D. (2008). Knowledge about language and learner autonomy. In J. Cenoz \& N. H. Hornberger (Eds.), Encyclopaedia of language and education, 2nd Edition, Volume 6: Knowledge about Language (pp. 247-258). New York: Springer Science.

Myartawan, I. P. N. W., Latief, M. A., \& Suharmanto. (2013). The correlation between learner autonomy and English proficiency of Indonesian EFL college learners. TEFLIN Journal, 24(1), 63-81.

Okumuş-Ceylan, N. (2014). The effect of language learning strategy training on learner autonomy and foreign language achievement. (Unpublished doctoral dissertation, Gazi University, Ankara, Turkey).

Oktay, A. (2015). Foreign language teaching: A problem in Turkish education. Procedia - Social and Behavioral Sciences, 174, 584 - 593.

Patton, M. Q. (2014). Qualitative research and evaluation methods. Thousand Oaks, CA: Sage Publishing.

Pearson, L. C., \& Moomaw W. (2005). The relationship between teacher autonomy and stress, work satisfaction, empowerment and professionalism. Educational Research Quarterly, 28(1), 37-53.

Ribbe, E., \& Bezanilla, M. J. (2013). Scaffolding learner autonomy in online university courses. Digital Education Review, 24, 98-113.

Scharle, A. \& Szabo, A. (2000). Learner autonomy: A guide to developing learner responsibility. Cambridge: Cambridge University Press.

Sert, N. (2006). EFL student teachers' learning autonomy. Asian EFL Journal, $8(2), 180-201$.

Tschirhart, C., \& Rigler, E. (2009). LondonMet e-packs: A pragmatic approach to learner/teacher autonomy. Language Learning Journal, 37(1), 71-83.

Yıldırım, Ö. (2005). ELT student's perceptions and behavior related to learner autonomy as learners and future teachers (Unpublished master's thesis, Anadolu University, Eskişehir, Turkey). 
46 TEFLIN Journal, Volume 30, Number 1, January 2019

Yumuk, A. (2002). Letting go of control to the learners: The role of the Internet in promoting a more autonomous view of learning in an academic translation course, Educational Research, 44(2), 141-156. 